\title{
ANALISIS HUKUM ISLAM TERHADAP PERSAINGAN USAHA HOME INDUSTRY TAPE KETAN CIBEUREUM
}

\author{
Didi Sukardi, Slamet Firdaus dan Ima Sri Fatmawati \\ Fakultas Syari'ah dan Ekonomi Islam \\ Institut Agama Islam Negeri Syekh Nurjati Cirebon \\ e-mail: didisukardimubarrak@gmail.com,slamet.firdaus@yahoo.com \\ dan srifatmawatiima@gmail.com
}

\begin{abstract}
Seeing the business opportunities are getting better in the business of glutinous tape production, no wonder if the people of Kuningan District special in Cibeureum Village many who wrestle the business. Of the many business actors emerged the competition, the result of the many competitions that occur arise unfair business competition model due to fraud. The method used in this research is qualitative by utilizing Islamic law approach. Techniques of data collection conducted, namely observation, interview and documentation. The results of this study indicate that the competition of home industry sticky tape industry in Cibeureum Village is included in the model of unfair business competition, because there are dis honest businessman cheating in doing business or business. Fraud is caused by dishonest businessmen (cheaters) who do not want to include the composition of the use of synthetic dyes (additional) on sticky tape label label packaging. So that consumers do not know, because of the unspoiled measures that are not justified by Islamic Law in carrying out economic transactions.
\end{abstract}

Keywords: Competition, Business, Home Industry, and Islamic Law.

\begin{abstract}
Abstrak
Melihat peluang usaha yang semakin baik dalam usaha produksi tape ketan, tak heran jika masyarakat Kabupaten Kuningan khusus nya di Desa Cibeureum banyak yang menggeluti usaha tersebut. Dari banyaknya pelaku usaha timbulah persaingan, akibat dari banyaknya persaingan yang terjadi timbulah model persaingan usaha tidak sehat karena adanya kecurangan. Metode yang digunakan dalam penelitian ini adalah kualitatif dengan memanfaatkan pendekatan hukum Islam. Teknik pengumpulan data yang dilakukan, yaitu observasi, wawancara dan dokumentasi. Hasil dari penelitian ini menunjukkan bahwa persaingan usaha home industry tape ketan di Desa Cibeureum termasuk pada model persaingan usaha tidak sehat, karena terdapat kecurangan pengusaha yang tidak jujur dalam melakukan usaha atau bisnis. Kecurangan tersebut diakibatkan dari pengusaha tidak jujur (curang) yang tidak mau mencantumkan komposisi penggunaan bahan pewarna sintetis (tambahan) pada tape ketan dilabel merek kemasannya. Sehingga konsumen tidak mengetahuinya, oleh karena ketidakterbukaan tersebut langkah itu tidak dibenarkan oleh Hukum Islam dalam menjalankan transaksi ekonomi.
\end{abstract}

Kata Kunci: Persaingan, Usaha, Home Industry, dan Hukum Islam. 


\section{PENDAHULUAN}

Persaingan dalam dunia usaha merupakan hal yang tidak bisa dihindarkan, karena memang kondisi yang mengharuskan. Pada perkembangannya sering dalam persaingan usaha, terdengar istilah monopoli. Secara singkat monopoli dapat diartikan sebagai penguasaan pasar atas satu orang saja. Sedangkan pelakunya sendiri disebut monopolis. Namun, secara luas monopoli dapat diartikan "terjadinya konsentrasi pasar dalam menentukan harga, produk dan keputusan-keputusan lain tentang pemasaran barang dan jasa".

Persaingan sangat dibutuhkan dalam peningkatan kualitas hidup manusia. Untuk terciptanya keadilan dan kesejahteraan bagi semua pihak, persaingan yang harus dilakukan adalah persaingan yang sehat. Persaingan yang semakin ketat, para pengusaha dituntut untuk memutar otaknya supaya usahanya tetap berjalan sehingga produknya laris di pasaran. Tuntutan itulah yang menjadikan sebagian para pengusaha untuk melakukan praktek kecurangan dalam berproduksi. Seharusnya mereka tetap mengutamakan kejujuran agar terciptanya persaingan yang sehat. Begitu pula yang terjadi pada persaingan usaha Home Industry Tape Ketan di Desa Cibeureum Kecamatan Cibeureum Kabupaten Kuningan. Terdapat beberapa pengusaha yang melakukan kecurangan dengan tidak mencantumkan penggunaan pewarna tambahan (sintetis) pada tape ketan di komposisi label merek jualnya. Cara ini memungkinkan terjadinya ketidakterbukaan penjual pada pembeli, karena tidak semua pembeli mengetahui bahwa tape ketan tersebut menggunakan tambahan pewarna buatan (sintetis) yang tidak dicantumkan pada komposisi label merek.

Dari uraian di atas, penelitian ini merumuskan permasalahan sebagai berikut; 1) Bagaimana model persaingan usaha home

\footnotetext{
${ }^{1}$ Nurimansjah Hasibuan, Ekonomi Industri: Persaingan, Monopoli dan Regulasi (Jakarta: LP3ES, 1994), 70.
}

industry tape ketan di Desa Cibeureum Kecamatan Cibeureum Kabupaten Kuningan? 2) Bagaimana bentuk kecurangan yang dilakukan oleh home industry tape ketan di Desa Cibeureum Kecamatan Cibeureum Kabupaten Kuningan dan dampaknya dalam hal persaingan usaha? 3) Bagaimana persaingan usaha home industry tape ketan di Desa Cibeureun Kecamatan Cibeureum Kabupaten Kuningan ditinjau dari perspektif Hukum Islam?

\section{LITERATUR REVIEW}

Penelitian tentang persaingan usaha bukanlah suatu yang baru. Meskipun demikian, nampaknya belum ditemukan penelitian yang secara spesifik dikaji dari segi hukum Islam. Berikut beberapa karya yang terdokumentasikan terkait permasalahan yang dikaji, yaitu pertama, Muhammad Saifullah, "Etika Bisnis Dalam Praktek Bisnis Rasulullah". ${ }^{2}$ Menurut Saifullah bahwa selama ini banyak orang memahami bisnis adalah bisnis yang tujuan utamanya memperoleh keuntungan sebanyak-banyaknya. Hukum ekonomi klasik yang mengendalikan modal sekecil mungkin dan mengeruk keuntungan sebesar mungkin telah menjadikan para pelaku bisnis menghalalkan segala cara untuk meraih keuntungan, mulai dari cara memperoleh bahan baku, bahan yang digunakan, tempat produksi, tenaga kerja pengelolaanya, dan pemasarannya dilakukan seefektif dan seefisien mungkin. Hal ini tidak mengherankan jika para pelaku bisnis jarang memperlihatkan tanggung jawab sosial dan mengabaikan etika bisnis.

Kedua, penelitian Erna Mardiyah dan Asep Suryanto dalam "Analisis Penerapan Etika Bisnis Syari'ah di Pasar Tradisional Singaparna Kab. Tasikmalaya". ${ }^{3}$

${ }^{2}$ Muhammad Saifullah, "Etika Bisnis Dalam Praktek Bisnis Rasulullah", Jurnal Hukum Islam, Vol. 19, No. 1 (Mei, 2011): 128.

${ }^{3}$ Erna Mardiyah dan Asep Suryanto, "Analisis Penerapan Etika Bisnis Syari'ah di Pasar Tradisional Singaparna Kab. Tasikmalaya”, 
Dalam penelitian tersebut dinyatakan bahwa dewasa ini masih banyak ditemukan para pedagang yang mengabaikan etika dalam menjalankan binisnya. Masih banyak para pedagang yang melakukan penyimpanganpenyimpangan dalam berdagang. Masalah yang rawan terjadi penyimpangan adalah pasar tradisional. Beberapa penyimpangan yang sering ditemukan di pasar tradisional antara lain pengurangan takaran dan timbangan, pengoplosan barang kualitas bagus dengan yang kualitas buruk, dan penjualan barang haram.

Dan ketiga, penelitian yang dilakukan oleh Desy Aty Purnama ${ }^{4}$ pada tahun 2015 yang berjudul "Analisis Persaingan Minimarket Dengan Pedagang Kecil Menurut Perspektif Hukum Ekonomi Syrai'ah (Studi Kasus Jalan Prjuangan II Harapan Mulya Cirebon)". Penelitian ini membahas tentang persaingan yang dilakukan oleh pihak minimarket, dengan pihak para pedagang kecil disekitarnya masih dalam lingkup persaingan sehat. Karena tempat mereka yang jarak diantara keduanya berdekatan bahkan sampai 20 meter dekatnya, maka salah satu dari mereka harus ada yang tersisihkan. Sudah jelas para pedagang kecilah yang merasakan kerugiannya, karena pelanggannya mulai tertarik oleh minimarket yang mana tempat nya cukup nyaman untuk dikunjungi belanja, lain halnya dengan toko kecil yang terkadang orang enggan untuk memasukinya.

Dari ketiga topik penelitian yang telah dipaparkan di atas, ternyata belum ada tinjauan secara khusus dan komprehensif tentang persaingan usaha home industry tape ketan yang ditinjau dari perspektif hukum Islam. Dengan menggunakan pendekatan hukum Islam ini, selain nantinya akan tergambar karakteristik persaingan

Penelitian Kolektif (Tasikmalaya: Universitas Tasikmalaya, 2010), 2.

${ }^{4}$ Desy Aty Purnama, "Analisis Persaingan Minimarket dengan Pedagang Kecil Menurut Perspektif Hukum Ekonomi Syari'ah", Skripsi (Cirebon: IAIN Syekh Nurjati Cirebon, 2015). usaha antar home industry, diharapkan penelitian ini juga akan mengungkapkan nuansa pembaharuan pemikiran hukum Islam sesuai dengan perkembangan zaman saat ini. Di sinilah letak perbedaan studi ini dengan studi-studi yang telah dilakukan sebelumnya.

\section{METODOLOGI PENELITIAN}

Jenis penelitian adalah penelitian lapangan (Field Research). Penelitian ini menggunakan jenis metode kualitatif atau penelitian lapangan. ${ }^{5}$ Penelitian lapangan merupakan penelitian yang dilakukan dalam kehidupan sehari-hari atau kehidupan yang sebenarnya. Ide penting dalam penelitian lapangan ini adalah peneliti berangkat ke lapangan untuk mengadakan pengamatan tentang suatu fenomena dalam suatu keadaan alamiah. ${ }^{6}$ Pada penelitian lapangan ini peneliti mengamati fenomena yang terjadi di dalam praktik persaingan usaha home industry tape ketan ditinjau dari hukum Islam studi kasus di Desa Cibeureum Kecamatan Cibeureum Kabupaten Kuningan pada bulan Maret-April 2017 dengan membuat catatan yang ekstensif.

Metode yang digunakan dalam penelitian ini adalah metode kualitatif, yaitu peneliti bermaksud untuk memahami fenomena tentang apa yang dialami oleh subjek penelitian seperti, perilaku, persepsi, motivasi, tindakan dan lainnya, secara holistik dan dengan suatu konteks khusus yang alamiah dan dengan memanfaatkan berbagai metode alamiah pula. ${ }^{7}$

Pendekatan penelitian yang dilakukan menggunakan pendekatan hukum Islam, yaitu melihat melihat kejadian sesuai realita sebagai fenomena sosial. Pada praktiknya, hal ini dilakukan untuk mengetahui eksistensi perspektif hukum

${ }^{5}$ Lexy J. Moleong, Metodologi Penelitian Kualitatif (Bandung: PT Remaja Rosdakarya, 2013), 26.

Kualitatif, 27.

${ }^{6}$ Lexy J. Moleong, Metodologi Penelitian

${ }^{7}$ Lexy J. Moleong, Metodologi Penelitian Kualitatif, 27. 
Islam dalam praktik persaingan usaha home industry tape ketan di Desa Cibeureum.

Sumber data yang diperlukan adalah data primer dan data sekunder. Data primer menurut Indriantoro data primer merupakan sumber data penelitian yang diperoleh secara langsung dari sumber asli (tidak melalui media perantara $)^{8}$, yang didapatkan melalui wawancara dengan informan diantaranya pengusaha tape ketan, konsumen, dan dinas perindustrian dan perdagangan Kabupaten Kuningan. Adapun data sekunder merupakan data yang bersumber dari buku dan majalah ilmiah yang berkaitan dengan pembahasan judul proposal ini sebagai rujukan atau bahan acuan $^{9}$, data sekunder yang digunakan disini yaitu skripsi, jurnal, dan website yang berkaitan dengan jual beli borongan, serta data dari Kantor Balai Desa Cibeureum.

Metode pengumpulan data yang digunakan adalah observasi, wawancara dan dokumentasi. Pertama, dilihat dari segi proses pengumpulan data, Tekhnik observasi adalah suatu tekhnik pengumpulan data dengan melakukan pengamatan dan pencatatan secara sistematis terhadap gejala fenomena yang diselidiki. ${ }^{10}$ Dalam hal ini penulis akan mengobservasi strategi perusahaan terhadap persaingan global. Penelitian ini bertujuan untuk mengetahui kecurangan yang dilakukan perusahaan dalam hal persaingan usaha. Observasi dapat dibedakan menjadi dua, yaitu observasi berperan serta dan observasi tidak berperan serta. ${ }^{11}$ Pada teknik pengumpulan data dengan observasi ini peneliti menggunakan observasi non participant observation (observasi tidak

\footnotetext{
${ }^{8}$ Nur Indriantoro, Metode Penelitian Bisnis untuk Akuntansi dan Manajemen (Yogyakarta: BPFE, 1999), 146.

${ }^{9}$ Lexy J. Moleong, Metodologi Penelitian Kualitatif, 159.

${ }^{10}$ Sutrisno Hadi, Metodologi Research (Yogyakarta: Penerbit Andi, 2014), 151.

11 Sugiono, Metode Penelitian Kuantitatif Kualitatif dan $R$ \& $D$ (Bandung: Alfabeta, 2012), 145 .
}

berperan serta), dalam teknik ini peneliti hanya sebagai pengamat independen tanpa ikut terlibat langsung dengan aktivitas orang-orang yang sedang diamati. Peneliti mengamati bagaimana perilaku masyarakat dalam praktik persaingan usaha home industry tape ketan, kemudian mencatat, menganalisis dan kemudian dapat membuat kesimpulan.

Kedua, wawancara adalah proses memperoleh keterangan untuk tujuan penelitian dengan cara tanya jawab, sambil bertatap muka antara pewawancara dengan responden dengan menggunakan alat yang dinamakan panduan wawancara. ${ }^{12}$ Dalam hal ini peneliti mewawancarai beberapa informan yang aktif melakukan praktik persaingan usaha home industry ditinjau dari hukum Islam (Studi kasus di Desa Cibeureum Kecamatan Cibeureum Kabupaten Kuningan).

Dan Ketiga, dokumentasi adalah mencari data mengenai hal-hal atau variabel yang berupa catatan, transkrip, buku, surat kabar, majalah, prasasti, dan sebagainya. ${ }^{13}$ Maksud dari dokumentasi ini peneliti mencari sumber-sumber data yang lain selain wawancara dan observasi yang berkaitan dengan kajian yang dibahas. Seperti misalnya buku-buku yang relevan, laporan kegiatan, foto-foto, film dokumenter dan data yang relevan.

Penelitian ini menggunakan teknis analisis data yang bersifat induktif yaitu suatu analisis berdasarkan data yang diperoleh, selanjutnya dikembangkan menjadi hipotesis. Hipotesis yang dirumuskan berdasarkan data tersebut, selanjutnya dicarikan data lagi secara berulang-ulang sehingga selanjutnya dapat disimpulkan apakah hipotesis tersebut diterima atau ditolak berdasarkan data yang terkumpul. Apabila data yang dikumpulkan secara berulang-ulang dengan tekhnik

12 Sugiono, Metode Penelitian Kuantitatif Kualitatif dan $R \& D, 153$.

13 Sugiono, Metode Penelitian Kuantitatif Kualitatif dan $R \& D, 166$. 
triangulasi (bermacam-macam), ternyata hipotesis diterima, maka hipotesis tersebut berkembang menjadi teori. ${ }^{14}$

\section{KONSEP DASAR}

\section{Persaingan Usaha dalam Islam}

Persaingan berasal dari bahasa Inggris yaitu competition yang artinya persaingan itu sendiri atau kegiatan bersaing, pertandingan, kompetisi. Sedangkan dalam kamus manajemen, persaingan adalah usaha-usaha dari dua pihak atau lebih perusahaan yang masing-masing bergiat, memperoleh pesanan dengan menawarkan harga atau syarat yang paling menguntungkan. Persaingan ini dapat terdiri dari beberapa bentuk pemotongan harga, iklan/promosi, variasi dan kualitas, kemasan, desain, dan segmentasi pasar. ${ }^{15}$ Definisi lain dari usaha adalah kegiatan dengan mengerahkan tenaga, pikiran, atau badan untuk mencapai suatu maksud; pekerjaan (perbuatan, prakarsa, ikhtiar, daya upaya) untuk mencapai sesuatu kegiatan di bidang perdagangan (dengan maksud mencari untung); perdagangan; perusahaan. ${ }^{16}$

Menurut Murdeni Muis, perilaku wirausaha muslim itu harus sesuai dengan ajaran agama Islam, dan harus memiliki konsep yang berbeda yakni menggunakan konsep keadilan, sehingga konsep syari'ah akan dapat mencapai masyarakat yang adil dan makmur. Ada beberapa perilaku Rasulullah SAW, yang harus ditiru oleh ummatnya dalam berbisnis (Usaha) yaitu diantaranya: ${ }^{17}$

Pertama, meyakini kerja sebagai ibadah, dengan keyakinan bahwa apapun yang dikerjakannya ibadah, maka semangat akan timbul dari dalam diri dalam

\footnotetext{
${ }^{14}$ Sugiono, Metode Penelitian Kuantitatif Kualitatif dan $R \& D, 245$.

${ }^{15} \mathrm{~S}$. Ramadhan, artikel Persaingan Usaha. http://digilib.uinsby.ac.id/1734/5/Bab\%202.pdf. Diakses pada tanggal 10 April 2018.

${ }^{16}$ Kamus Besar Bahasa Indonesia (KBBI).

${ }^{17}$ S. Ramadhan, artikel Persaingan Usaha. http://digilib.uinsby.ac.id/1734/5/Bab\%202.pdf. Diakses pada tanggal 10 April 2018.
}

menjalankannya. Allah menyerukan manusia untuk bekerja dengan sungguhsungguh agar lebih memahami dan menghargai waktu dengan aktifitas yang bernilai ibadah.

Kedua, kreatif, perilaku pengusaha kreatif akan menciptakan suatu barang yang baru atau metode baru sehingga menarik untuk dipasarkan. Kreatif diartikan dengan melakukan atau menciptakan hal-hal yang baru dari sebelumnya, ada 3 manfaat kreatif, yaitu: menghindarkan dari kejenuhan, membuat hidup lebih hidup. Islam memberikan perhatian besar bagi pentingnya penguasaan keahlian seperti kekreatifan.

Ketiga, memiliki pengetahuan, tentu semua pebisnis memiliki pengetahuan yang berbeda. Namun, bagi perilaku muslim mengetahui dan mempraktikkan bisnis ala Rasulillah merupakan satu hal yang wajib. Pengetahuan itu diantaranya mengetahui peluang usaha, mengetahui bagaimana menghadapinya.

Keempat, visioner, ada empat paradigma yang menjadi landasan pengusaha yang visioner, yaitu: mampu memprediksi kemungkinan di masa yang akan datang, penyesuaian terhadap lingkungan kerja, harus dinamis dalam mengantisipasi berbagai macam kemungkinan, kemampuan melanjutkan perubahan dari aturan atau bentuk yang telah ada sebelumnya. ${ }^{18}$

Prinsip terpenting yang mengatur seluruh aktivitas ekonomi adalah keadilan, yang berarti perdagangan jujur, terbuka, transparansi dengan sesama dan menjaga keseimbangan keadilan. Syariah menaruh keutamaan besar bagi peran informasi dalam pasar. Seseorang harus memberikan kesempatan luas kepada klien untuk melihat dan memeriksa komoditas yang akan dibelinya. Informasi yang tidak akurat atau

\footnotetext{
${ }^{18} \mathrm{~S}$. Ramadhan, artikel Persaingan Usaha. http://digilib.uinsby.ac.id/1734/5/Bab\%202.pdf. Diakses pada tanggal 10 April 2018.
} 
menipu adalah dilarang dan dinilai sebagai sebuah dosa. ${ }^{19}$

\section{Dasar Hukum Persaingan Usaha dan Jual Beli Secara Transparan}

Persaingan sebagai sarana untuk berlomba antara sesaama umat manusia mempunyai landasan yang kuat dalam Al-Qur'an dan sunah Rasulullah saw. Terdapat beberapa ayat Al-Qur'an dan sunah Rasulullah SAW, yang berbicara tentang persaingan, antara lain:

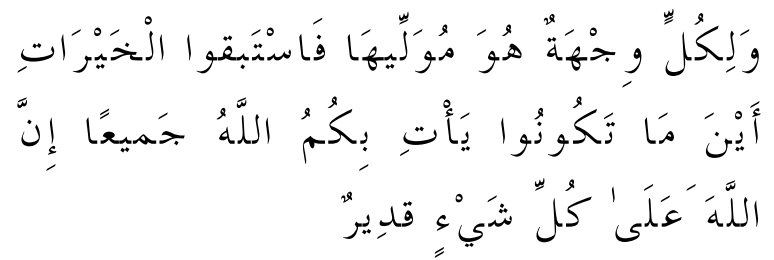

Artinya: Dan setiap umat mempunyai kiblat yang dia menghadap kepadanya. Maka berlomba-lombalah kamu dalam kebaikan. Dimana saja kamu berada, pasti Allah akan mengumpulkan kamu semuanya. Sungguh, Allah Maha Kuasa atas segala sesuatu. ${ }^{20}$

M. Quraish Shihab dalam bukunya yang berjudul Tafsir Al-Mishbah menyatakan bahwasannya kiblat yang aku perintahkan dirimu, Muhammad, untuk beralih kepadanya (Ka'bah), bukan hanya untuk mu saja tetapi juga kiblat umatmu. Demikianlah, bahwa tiap umat memiliki kiblat tempat mereka menghadap dalam salat sesuai syariat masing-masing. Dalam hal ini Tuhan tidak bermaksud melebihkan satu umat atas umat yang lain, karena kelebihan itu sesungguhnya terletak pada kadar ketaatan dan kebajikan. Maka berlomba-lomba dan bersainglah dalam mengejar berbagai kebaikan dan Allah akan membalas perbuatan baik kalian. Allah akan mengumpulkan kalian semua di mana pun berada dan tidak akan ada seorang pun yang luput dari perhitungan-Nya. Di tanganNyalah kekuasaan untuk mematikan,

\footnotetext{
${ }^{19}$ Veithzal Rivai, et.al., Islamic Business and Economic Ethics (Jakarta: Bumi Aksara, 2012), 404.

${ }^{20} \mathrm{QS}$. Al-Baqarah (2): 148.
}

menghidupkan, membangkitkan manusia dan mengumpulkannya di hari kiamat. ${ }^{21}$

Berdasarkan tafsir tersebut jelas menunjukkan bahwa harta (kekayaan materi) hasil dari muamalah merupakan bagian yang sangat penting dalam kehidupan kaum muslimin. Dengan demikian, sah-sah saja apabila seorang muslim giat berlomba dalam mencari rezeki untuk memenuhi segala kebutuhan hidupnya. Hanya saja seorang muslimin harus mencerminkan perilaku yang baik pula tentunya dan tidak terlepas dari normanorma berbisnis menurut syari'at Islam untuk mencari rezeki tersebut. Sehingga, nilai ibadah dalam mencari rezeki tidak hilang dan tidak berubah menjadi perilaku tercela yang tidak dibenarkan dalam syari'at Islam.

Dasar hukum jual beli dengan transparan tanpa ada yang ditutup-tutupi antara penjual dan pembeli berdasarkan Hadits yang diriwayatkan oleh Abu Hurairah ra:

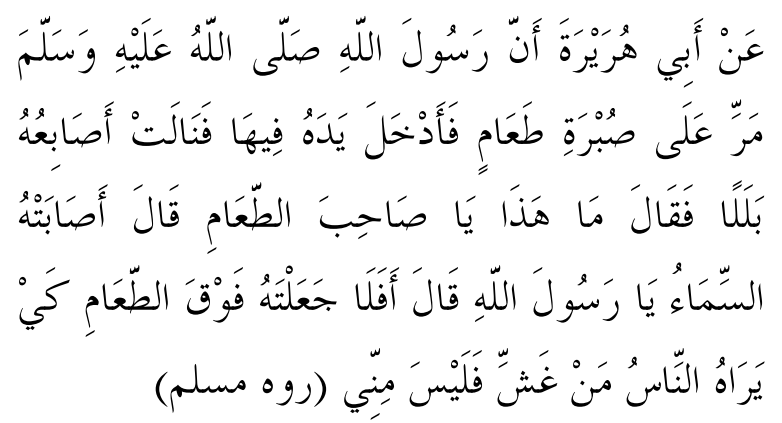

Artinya: Dari Abu Hurairah ra bahwa Rasulullah pernah melewati setumpuk makanan, lalu beliau memasukkan tangannya ke dalamnya, kemudian tangan beliau menyentuh sesuatu yang basah, maka pun beliau bertanya, "Apa ini wahai pemilik makanan?" Sang pemiliknya menjawab, "Makanan tersebut terkena air hujan wahai Rasulullah." Beliau bersabda,

\footnotetext{
${ }^{21}$ M. Quraish Shihab, Tafsir al-Mishbah: Pesan, Kesan dan Keserasian Al-Qur'an (Jakarta: Lentera Hati, 2005).
} 


$\begin{array}{lcr}\text { "Mengapa } & \text { kamu } & \text { tidak } \\ \text { meletakkannya } & \text { di } & \text { bagian } \\ \text { makanan agar } & \text { manusia dapat } \\ \text { melihatnya? } & \text { Ketahuilah, } \\ \text { barangsiapa menipu maka dia } \\ \text { bukan dari golongan kami. }{ }^{22}\end{array}$

Bahan makanan yang di atas tampak bagus, tidak ada cacat/rusaknya. Namun ketika memasukkan jari-jemari beliau ke dalam tumpukan bahan makanan tersebut, beliau dapatkan ada yang basah karena kehujanan (yang berarti bahan makanan itu ada yang rusak). Penjualnya meletakkannya di bagian bawah agar hanya bagian yang bagus yang dilihat pembeli. Rasulullah pun menegur perbuatan tersebut dan mengecam demikian kerasnya. Karena hal ini berarti menipu pembeli, yang akan menyangka bahwa seluruh bahan makananan itu bagus. Seharusnya seorang mukmin menerangkan keadaan barang yang akan dijualnya, terlebih lagi apabila barang tersebut memiliki cacat ataupun aib.Selain itu juga harus berprinsip bahwa persaingan bukanlah usaha untuk menjatuhkan pembisnis lainnya melainkan sebagai usaha untuk memberikan yang terbaik dari usahanya. Islam pun memperkenalkan konsep halal dan haram dalam sistem ekonomi, Fondasi perekonomian terletak pada konsep ini karena konsep ini memegang peran amat penting baik dalam wilayah produksi maupun konsumsi. ${ }^{23}$ Untuk itu produsen harus memperhatikan norma-norma yang ada dalam ketentuan Islam dalam menjalankan usaha nya.

Produsen akan berusaha menggunakan faktor-faktor yang ada untuk memproduksi berbagai jenis barang kebutuhan yang diminta oleh konsumen. Lazimnya produsen selalu berprinsip "memproduksi barang dengan biaya yang relatif rendah untuk memksimumkan keuntungan yang akan diperoleh".

\footnotetext{
${ }^{22}$ Muhammad Sharif Chaudhry, Sistem Ekonomi Islam (Jakarta: Kencana, 2012), 9-10.

${ }^{23}$ Muhammad Sharif Chaudhry, Sistem Ekonomi Islam, 9-10.
}

Meskipun demikian, apabila aktivitas produsen dipengaruhi oleh semangat ruh Islam, maka aktivitasnya akan diselaraskan dengan norma-norma yang ada dalam ketentuan syariat Islam. $^{24}$

Dari kandungan ayat-ayat Al-Qur'an dan Hadits diatas, para ulama fiqh menyatakan bahwa hukum asal dari persaingan usaha itu boleh.

\section{Model Persaingan Usaha}

Persaingan Usaha merupakan sebuah tolak ukur yang dapat digunakan untuk memastikan bahwa seluruh pihak yang terlibat dalam sebuah kegiatan usaha tidak melanggar kepentingan satu sama lain dan memberikan jaminan bahwa setiap orang yang berusaha di Indonesia berada dalam persaingan yang sehat dan wajar. Hal ini menjadikan persaingan usaha harus diperhatikan oleh para pelaku usaha dalam menjalankan kegiatan usahanya, baik sebelum maupun setelah usahanya dijalankan. ${ }^{25}$ Ditinjau dari modelnya, persaingan usaha ada dua macam yaitu persaingan usaha sehat yang berarti persaingan yang sesuai dengan agama dan dibolehkan oleh hukum, dan persaingan usaha tidak sehat yaitu persaingan usaha yang tidak sesuai dengan agama dan dilarang oleh hukum.

Persaingan usaha sehat adalah persaingan antara pelaku usaha dalam menjalankan kegiatan produksi barang dan atau jasa yang dilakukan dengan jujur dan tidak melawan hukum. Persaingan sehat dan jujur sangat diperlukan bagi membina kekuatan lembaga-lembaga usaha, dari berbagai skala usaha yang ada sehingga kegiatan ekonomi berjalan secara efisien. ${ }^{26}$

${ }^{24}$ Suhrawardi K. Lubis dan Farid Wajdi, Hukum Ekonomi Islam (Jakarta: Sinar Grafika, 2012), 24.

${ }^{25}$ Abdul Hakim G. Nusantara, Erman, HMBC R., Litigasi Persaingan Usaha, dalam http://obor.or.id/litigasi-persaingan-usaha diakses pada tanggal 10 April 2018.

${ }^{26}$ Bchtiar Hassan Miraza, Manajemen Bisnis (Bandung: ISEI Bandung, 2004), 20. 
Persaingan usaha yang sehat seperti ini justru akan melahirkan pengusaha yang tangguh dan terpercaya di dalam menghadapi iklim ekonomi global. Perlu ditegaskan bahwa penciptaan persaingan usaha yang sehat haruslah dimulai dari pembenahan perilaku pengusaha. ${ }^{27}$

Persaingan usaha tidak sehat Persaingan bisnis (usaha) tidak sehat adalah persaingan antara pelaku usaha dalam menjalankan kegiatan produksi dan atau pemasaran barang dan atau jasa yang dilakukan dengan cara tidak jujur atau melawan hukum sehingga menghambat persaingan usaha. ${ }^{28}$ Berbagai pelanggaran yang terjadi bisa dalam bentuk manipulasi ukuran, harga, kualitas, merk dan lain sebagainya, yang ada kaitannya dengan transaksi perdagangan yang terjadi. Namun pelanggaran ini berjalan secara terselubung sehingga tidak disadari oleh pihak pembeli. Posisi konsumen/pembeli dinilai rendah oleh pengusaha karena mereka tidak kritis pada saat melakukan pembelian sehingga merugikan konsumen sendiri. Agaknya hal ini merupakan ciri khas masyarakat konsumen dari negara-negara berkembang. Keadaan yang seperti ini dimanfaatkan pengusaha untuk melakukan hal-hal yang sebenarnya dilarang dalam kegiatan bisnis. ${ }^{29}$

Persaingan usaha tidak sehat biasanya mengandung unsur: (1) Gharar yaitu ketidak pastian dalam suatu akad, baik mengenai kualitas atau kuantitas objek akad maupun penyerahannya. (2) Taghrir yaitu upaya untuk mempengaruhi orang lain, baik dengan ucapan maupun tindakan yang mengandung kebohongan, agar terdorong

\footnotetext{
${ }^{27}$ Bchtiar Hassan Miraza, Manajemen Bisnis, 24.

${ }^{28}$ Aan Rahmawati, “Analisis Strategi Bersaing Dalam Pengembangan Produk pada CV. MUSTIKA FLAMBOYAN Desa Ciawigebang Kecamatan Ciawigebang Kabupaten Kuningan", Skripsi (Cirebon: Fakultas Syariah dan Ekonomi Islam Institut Agama Islam Negeri Syekh Nurjati Cirebon, 2015), 39.

Bisnis, 70-72.
}

untuk melakukan transaksi. (3) Jahalah yaitu ketidakjelasan dalam suatu akad, baik mengenai objek akad, kualitas atau kuantitas (shifatnya), harganya (tsaman), maupun mengenai waktu penyerahannya. (4) Ihtikar yaitu membeli suatu barang yang sangat diperlukan masyarakat pada saat harga mahal dan menimbunnya dengan tujuan untuk menjualnya kembali pada saat harganya lebih mahal. (5) Ghabn yaitu ketidak seimbangan antara dua barang (obyek) yang dipertukarkan dalam suatu akad, baik segi kualitas maupun kuantitasnya. (6) Ghabn Fahisy yaitu ghabn tingkat berat, seperti jual beli atas barang dengan harga jauh di bawah harga pasar. (7) Talaqqi al-rukban yaitu bagian dari ghabn; yaitu jual beli atas barang dengan harga jauh di bawah harga pasar karena pihak penjual tidak mengetahui harga tersebut. (8) Tadlis yaitu tindakan menyembunyikan kecacatan obyek akad yang dilakukan oleh penjual untuk mengelabui pembeli seolah-olah obyek akad tersebut tidak cacat. (9) Tanajusy atau Najsy yaitu tindakan menawar barang dengan harga lebih tinggi oleh pihak yang tidak bermaksud membelinya untuk menimbulkan kesan banyak pihak yang berminat membelinya. (10) Ghisysy yaitu salah satu bentuk tadlis; yaitu penjual menjelaskan atau memaparkan keunggulan atau keistimewaan barang yang dijual serta menyembunyikan kecacatannya. (11) Dharar yaitu tindakan yang dapat menimbulkan bahaya atau kerugian orang lain. $^{30}$

\section{Home Industry}

Home Industry adalah suatu industri yang di kerjakan di rumah dan berskala kecil. Menurut kamus kecil bahasa Indonesia pengertian home adalah rumah, sedangkan industry adalah perusahaan yang

${ }^{30}$ Aan Rahmawati, “Analisis Strategi Bersaing Dalam Pengembangan Produk pada CV. MUSTIKA FLAMBOYAN Desa Ciawigebang Kecamatan Ciawigebang Kabupaten Kuningan”, 3940. 
memproduksi barang-barang. Dalam suatu industri kecil pasti terdapat beberapa aspek yang dibutuhkan untuk bisa mendukung berjalannya suatu industri tersebut, diantaranya: modal, bahan baku, tenaga kerja, pemasaran, serta konsumen. ${ }^{31}$

\section{PEMBAHASAN DAN DISKUSI}

Model Persaingan Usaha Home Industry Tape Ketan di Desa Cibeureum kecamatan Cibeureum Kabupaten Kuningan

Berdasarkan hasil penelitian ke desa Cibeureum tentang model persaingan yang terjadi antara perusahaan home industry tape ketan, hasil penelitian menunjukan adanya model persaingan usaha yang tidak sehat, karena terdapat praktek-praktek kecurangan yang dilakukan oleh pengusaha dalam menjalankan usahanya. Persaingan usaha tidak sehat adalah persaingan antar pelaku usaha dalam menjalankan kegiatan produksi dan/atau pemasaran barang atau jasa yang dilakukan dengan cara yang tidak jujur atau melawan hukum atau menghambat persaingan usaha.

\section{Kecurangan dalam Persaingan Tidak Sehat}

Bentuk kecurangan dari persaingan usaha home industry tape ketan di desa Cibeureum, hasil data menunjukan yaitu: pertama, Kecurangan yang dilakukan pengusaha dalam penggunaan tambahan pewarna makanan sintetis (kimia) yang tidak dicantumkan pada label merek jual. Tindakan tidak mencantumkannya pada label merek penjualan produk tape tersebut, itu merupakan bentuk dari kecurangan pengusaha untuk tidak melakukan keterbukaan kepada konsumen. Sedangkan Allah melarang berlaku curang, dan merugikan orang lain. Rasulullah SAW melarang menipu, berbuat curang dan berbuat kejahatan dalam transaksi jual

\section{Bisnis, 72.}

beli. ${ }^{32}$ Kecurangan tersebut sudah termasuk kepada spekulasi pengusaha (gharar), yang mana secara bahasa gharar mempunyai arti hal yang tidak diketahui atas bahaya tertentu. Sedangkan menurut terminologi fiqih, gharar merupakan hal yang tidak diketahui terhadap akibat satu perkara/transaksi atau ketidakjelasan antara baik dan buruknya. ${ }^{33}$

Kedua, Manipulasi penggunaan pewarna makanan dalam label merek jual yang mencantumkan pewarna alami (daun pandan) padahal tidak menggunakannya. Manipulasi tersebut bisa dikategorikan penipuan terhadap konsumen. Padahal Rasulullah SAW juga melarang melakukan penipuan dalam jual-beli. Dari Abdullah bin Umar, RA, katanya "Seorang laki-laki bercerita kepada Rasulullah SAW bahwa dia ditipu orang dalam hal jual beli. Maka sabda beliau: "Apabila engkau berjual beli, maka katakanlah jangan menipu" (Bukhari dan Muslim). ${ }^{34}$ Dan ketiga, Pengoplosan bahan pewarna alami dengan pewarna makanan buatan (kimia), yang tentu di dalamnya terdapat kandungan zat-zat yang berbahaya apabila dikonsumsi secara rutin. Sehingga akan mengakibatkan beberapa gangguan pada organ dalam tubuh. Zat tersebut diantaranya yaitu Tartrazin CI 19140 yang akan memberikan warna kuning, dan Biru Berlian CI 42090 yang akan memberikan warna biru pada makanan. Campuran kedua zat tersebut yang akan menghasilkan warna hijau.

\section{Dampak dari Kecurangan}

Kandungan senyawa kimia pada pewarna buatan seperti Natrium Benzoat yang berguna sebagai bahan pengawet, Tartrazin

${ }^{32} \mathrm{M}$. Suyanto, Muhammad Business Strategy \& Ethics (Etika dan Strategi Bisnis Nabi Muhammad SAW) (Yogyakarta: ANDI, 2008), 203.

${ }^{33} \mathrm{M}$. Suyanto, Muhammad Business Strategy \& Ethics (Etika dan Strategi Bisnis Nabi Muhammad SAW), 209.

${ }^{34}$ M. Suyanto, Muhammad Business Strategy \& Ethics (Etika dan Strategi Bisnis Nabi Muhammad SAW), 201. 
CI 19140 dimana akan menghasilkan warna kuning dan Biru Berlian CI 42090 akan menghasilkan warna biru, sehingga perpaduan dari kedua warna tersebut akan menjadi warna hijau. Penggunaan zat tersebut pada makanan dapat menyebabkan sejumlah alergi dan intoleransi terhadap aspirin atau penderita asma. Gejala alergi terhadap tartrazin dapat timbul apabila senyawa ini terhirup atau ditelan. Gejala alergi yang dapat timbul diantaranya adalah sesak napas, pusing, migrain, pandangan kabur, serta sulit tidur.

Selain hal diatas dampak dari kecurangan yang dilakukan pengusaha bisa dirasakan oleh konsumen. Secara tidak langsung mereka dibohongi oleh pengusaha yang melakukan kecurangan dan tidak mau terbuka akan kecurangannya tersebut. Sehingga apabila mereka mengetahui kecurangan tersebut akan menimbulkan ketidak percayaan lagi bagi konsumen terhadap produk tape ketan di desa tersebut.

Dari ketidak percayaan tersebut maka akan merugikan pengusaha yang jujur dalam usahanya. Karena konsumen akan menilai bahwa semua pengusaha tape ketan di desa Cibeureum berbuat curang dan tidak memberi keterbukaan terhadap produksi tape ketannya. Padahal hasil survey membuktikan tidak semua pengusaha melakukan kecurangan, ada beberapa pengusaha yang masih mau mempertahankan kejujurannya dalam bersaing di dunia bisnis.

Persaingan Usaha Home Industry Tape Ketan Ditinjau dari Hukum Islam Studi Kasus di Desa Cibeureum Kecamatan Cibeureum Kabupaten Kuningan

Persaingan usaha antar home industry tape ketan di desa Cibeureum yang terjadi saat ini mengandung permasalahan dalam prakteknya karena terdapat pengusaha jujur yang kenyamanannya terganggu atas menjamurnya pengusaha home industry tape ketan yang melakukan praktek kecurangan. Persaingan ini dibuktikan dengan pernyataan para pengusaha tape ketan yang dirasakan oleh ibu Jum'ati pengusaha tape ketan Hegar Sari, yang mengatakan bahwa "Beliau merasa maraknya kehadiran pengusaha tape ketan yang melakukan kecurangan dalam berproduksi dapat mengancam citra baik para pengusaha tape ketan yang mempertahankan kejujurannya sehingga ketakutan akan membuat pendapatan para pengusaha jujur menurun dari biasanya". 35

Kehadiran pengusaha home industry tape ketan yang melakukan kecurangan ke tengah-tengah pengusaha yang jujur, menimbulkan dampak yang kurang baik terhadap mereka. Pengusaha curang dianggap tidak peduli akan keberlangsungan usaha pengusaha jujur melainkan berlombalomba untuk mendapatkan konsumen yang sebanyak mungkin. Dalam setiap aktifitas ekonomi dalam berbisnis yang dijalankan oleh setiap manusia tentunya tidak akan terlepas dari berbagai macam aturan hukum, karena setiap aktifitas tersebut menimbulkan permasalahan dan perselisihan diantara para pelakunya. Oleh karena itu, dalam ajaran agama Islam permasalahan yang terjadi dalam aktifitas bisnis diatur dalam bentuk aturan-aturan hukum Islam. Hukum Islam yang bersumber dari Al-Qur'an, As-Sunnah dan dari berbagai macam sumber hukum lainnya seperti cabang kaidah fiqih yang membantu menjawab permasalahan yang terjadi pada saat ini. ${ }^{36}$ Kecurangan dalam ekonomi telah di atur dalam al-Qur'an surat al-Muthaffifin ayat 1-3:

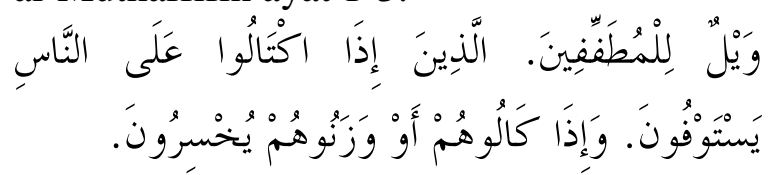

Artinya: Celakalah bagi orang-orang yang curang (dalam menakar dan menimbang. (Yaitu) orang-orang yang apabila menerima takaran

\footnotetext{
${ }^{35}$ Hasil Wawancara dengan Ibu Jum'ati pengusaha tape ketan "Hegar Sari", pada tanggal 26 April 2018.

${ }^{36}$ Desy Aty Purnama, "Analisis Persaingan Minimarket dengan Pedagang Kecil Menurut Perpsektif Hukum Ekonomi Syari'ah”, 74.
} 
dari orang lain mereka minta dipenuhi. Dan apabila mereka menakar atau menimbang (untuk orang lain), mereka mengurangi. ${ }^{37}$

M. Quraish Shihab dalam bukunya yang berjudul Tafsir Al-Mishbah menyatakan bahwa ayat tersebut berisi ancaman dari Allah yang menanti bagi orang-orang yang berbakti akan dimasukan ke surga sedangkan yang durhaka akan ditempatkannya di neraka. Salah satu hal yang paling banyak terjadi dalam hubungan antar manusia yakni menyangkut ukuran. Salah satu dosa yang terbesar adalah yang menyangkut ukuran dan timbangan. Ayat di atas merupakan ancaman kepada semua pihak agar tidak melakukan kecurangan dalam penimbangan dan pengukuran, termasuk dalam melakukan standar ganda. Perlakuan semacam ini bukan saja kecurangan, tetapi juga pencurian dan bukti kebejatan hati pelakunya. Di sisi lain, kecurangan ini menunjukkan pula keangkuhan dan pelecehan, karena biasanya pelakunya menganggap remeh mitranya sehingga berani melakukan hal tersebut. ${ }^{38}$

Begitu pula yang terjadi pada persaingan usaha Home Industry Tape Ketan di Desa Cibeureum Kecamatan Cibeureum Kabupaten Kuningan. Terdapat pengusaha yang melakukan kecurangan saat memproduksi tape ketan, dengan mengurangi takaran air perasan daun katuk sehingga mencampurkan pewarna makanan buatan kedalam air perasan daun katuknya tersebut untuk memperkuat warna hijau tape yang dihasilkan. Sedangkan apabila mereka memproduksi tape ketan untuk dikonsumsi bagi dirinya sendiri, mereka akan memperbanyak kandungan pewarna alami dari daun katuk dan mengurangi bahkan tidak menggunakan bahan pewarna tambahan yang bersifat kimia. Dengan

\footnotetext{
${ }^{37}$ QS. Al-Muthaffifin (83): 1-3.

${ }^{38}$ M. Quraish Shihab, Tafsir Al-Mishbah: pesan, kesan dan keserasian Al-Qur'an, 121.
}

alasan ketakutan akan berdampak buruk bagi tubuh apabila sudah dikonsumsi. sebaliknya mereka malah mengabaikan kesehatan para konsumen nya.

Islam tidak menghendaki pemeluknya menjadi mesin ekonomi yang melahirkan budaya materialisme (hedonisme). Kegiatan ekonomi dalam Islam tidak semata-mata bersifat materi saja, tetapi lebih dari itu (bersifat materi plus). Rakus terhadap kekayaan dan sikap mementingkan materi belaka sangat dicela. ${ }^{39}$

Dalam Islam diharuskan bersaing dengan cara yang dihalalkan tidak dengan cara yang diharamkan, jadi para pelaku usaha seharusnya berlomba-lomba untuk menarik konsumen dengan cara-cara yang baik pula. Allah SWT menegaskan bahwa dalam melakukan persaingan atau perlombaan dengan menggunakan cara yang dianjurkan oleh Allah SWT, dan jangan sesekali melakukan persaingan dengan cara yang bathil karena itu merupakan termasuk persaingan dalam keburukan. Islam juga telah menganjurkan umatnya untuk memakan makanan yang halal dan baik, telah diatur dalam al-Qur'an al-Maidah ayat 88:

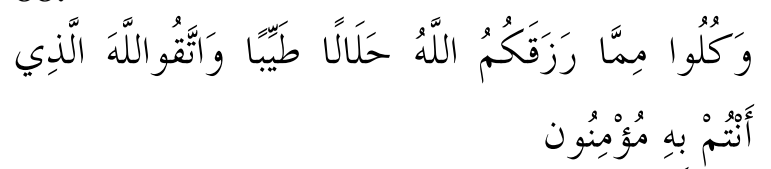

Artinya: Dan makanlah makanan yang halal lagi baik dari apa yang Allah telah rezekikan kepadamu, dan bertakwalah kepada Allah yang kamu beriman kepada-Nya. ${ }^{40}$

Bachtiar Surin dalam bukunya yang berjudul Az-Zikra terjemah dan tafsir menyatakan bahwa ayat tersebut berisi bukan hanya untuk menganjurkan memakan makanan yang baik saja tetapi juga meminum minuman yang baik. Sedangkan yang dimaksud dengan rezeki yang halal dalam ayat tersebut yaitu seperti kandungan

\footnotetext{
${ }^{39}$ Suhrawardi K. Lubis dan Farid Wajdi. Hukum Ekonomi Islam, 2012), 2.

${ }^{40} \mathrm{QS}$. Al-Maidah (5): 88.
} 
zat dalam makanan/minumannya itu sendiri. Berikutnya, halal dalam cara mendapatkannya misalnya dilarang memperoleh dari riba, pungutan liar, curian dan sebagainya. ${ }^{41}$

Dengan demikian, permasalahan yang terjadi di usaha home industry tape ketan desa Cibeureum tentang persaingan antar home industry masih belum sesuai dengan prinsip Islam, disebabkan sebagian besar produsen tape ketan tidak melakukan kontrol terhadap permintaan pasar yang akan menimbulkan adanya dampak negatif terhadap kualitas produk. Maka dari itu banyak bermunculan kehadiran pengusaha tape ketan yang berbuat curang menimbulkan berbagai macam masalah bagi para pengusaha yang berlaku jujur. Seperti citra produk mereka menurun, berkurangnya konsumen, sehingga pendapatan mereka juga dikhawatirkan ikut menurun dari biasanya. Pengusaha yang curang dianggap melenceng dari aturan prinsip hukum Islam dalam berbisnis.

\section{KESIMPULAN}

Berdasarkan penelitian di atas, dapat disimpulkan 3 (tiga) macam, yaitu pertama, Model persaingan usaha home industry tape ketan ditinjau dari hukum Islam studi Kasus di desa Cibeureum Kecamatan Cibeureum Kabupaten Kuningan, yaitu persaingan usaha home industry tape ketan yang bersifat tidak sehat.

Kedua, dalam parkteknya persaingan usaha home industry tape ketan di desa Cibeureum kecamatan Cibeureum Kabupaten Kuningan terdapat adanya kecurangan yang dilakukan oleh pengusaha yang tidak jujur meskipun tidak semuanya berbuat curang. Kecurangan tersebut disebabkan oleh pengusaha yang tidak jujur enggan melakukan keterbukaan terhadap jual beli tape ketan kepada konsumen, dengan mau mencantumkan penggunaan

\footnotetext{
${ }^{41}$ Bachtiar Surin, Az-Zikra: Terjemah dan Tafsir al-Qur'an dalam huruf Arab \& Latin juz 6-10 (Bandung: Angkasa, 2004), 487.
}

pewarna tambahan (sintetis) pada komposisi label merek jual tape ketannya. Akibat dari ketidakterbukaan tersebut memungkinkan konsumen untuk dirugikan sebagai info yang kurang jelas dari kejelasan kualitas tape ketan. Oleh karena itu bisa berdampak pada menurunnya kepercayaan dari konsumen terhadap produk tape ketan di desa Cibeureum tersebut. Padahal tidak semua pengusahanya melakukan ketidakterbukaan pada produk tape ketannya.

Dan ketiga, praktek persaingan usaha home industry tape ketan yang dilakukan oleh pengusaha tape ketan desa Cibeureum Kecamatan Cibeureum Kabupaten Kuningan dapat dikatakan tidak sesuai dengan prinsip-prinsip syari'ah, dengan berlandaskan pada persaingan yang bersifat tidak sehat. Disebut persaingan tidak sehat karena disebabkan adanya ketidakterbukaan dari pengusaha yang tidak jujur terhadap produk tape ketan yang diproduksinya. Pengusaha tidak jujur tersebut enggan mencantumkan penggunaan tambahan pewarna buatan (sintetis) pada label merek jualnya. Padahal apabila mereka mencantumkan, maka sesuai dengan prinsip syariah dalam melakukan jual beli yang memang seharusnya bersifat terbuka tidak ada yang ditutup-tutupi dari pihak penjual terhadap pembeli.

\section{DAFTAR PUSTAKA}

Abdul Hakim G. Nusantara, Erman, HMBC R. Litigasi Persaingan Usaha, dalam http://obor.or.id/litigasi-persainganusaha.

Chudhry, Muhammad Sharif. Sistem Ekonomi Islam. Jakarta: Kencana, 2012.

Desy Aty Purnama, "Analisis Persaingan Minimarket dengan Pedagang Kecil Menurut Perspektif Hukum Ekonomi Syari'ah", Skripsi (Cirebon: IAIN Syekh Nurjati Cirebon, 2015).

Hadi, Sutrisno. Metodologi Research. Yogyakarta: Penerbit Andi, 2014. 
Hasibuan, Nurimansjah. Ekonomi Industri: Persaingan, Monopoli dan Regulasi. Jakarta: LP3ES, 1994.

Indriantoro, Nur. Metode Penelitian Bisnis untuk Akuntansi dan Manajemen. Yogyakarta: BPFE, 1999.

Kamus Besar Bahasa Indonesia (KBBI).

Lubis, Suhrawardi K. dan Farid Wajdi, Hukum Ekonomi Islam. Jakarta: Sinar Grafika, 2012.

Mardiyah, Erna dan Asep Suryanto. "Analisis Penerapan Etika Bisnis Syari'ah di Pasar Tradisional Singaparna Kab. Tasikmalaya”, Penelitian Kolektif. Tasikmalaya: Universitas Tasikmalaya, 2010. 2.

Miraza, Bchtiar Hassan. Manajemen Bisnis. Bandung: ISEI Bandung, 2004.

Moleong, Lexy J. Metodologi Penelitian Kualitatif. Bandung: PT Remaja Rosdakarya, 2013.

Rahmawati, Aan. "Analisis Strategi Bersaing Dalam Pengembangan Produk pada CV. MUSTIKA FLAMBOYAN Desa Ciawigebang Kecamatan Ciawigebang Kabupaten Kuningan", Skripsi. Cirebon: Fakultas Syariah dan Ekonomi Islam Institut Agama Islam Negeri Syekh Nurjati Cirebon, 2015.

Ramadhan, S. Persaingan Usaha. http://digilib.uinsby.ac.id/1734/5/Ba b\%202.pdf.

Rivai, Veithzal, et.al. Islamic Business and Economic Ethics. Jakarta: Bumi Aksara, 2012.

Saifullah, Muhammad. "Etika Bisnis Dalam Praktek Bisnis Rasulullah", Jurnal Hukum Islam, Vol. 19, No. 1 (Mei, 2011).

Shihab, M. Quraish. Tafsir al-Mishbah: Pesan, Kesan dan Keserasian alQur'an. Jakarta: Lentera Hati, 2005.

Sugiono. Metode Penelitian Kuantitatif Kualitatif dan $R$ \& D. Bandung: Alfabeta, 2012.

Surin, Bachtiar. Az-Zikra: Terjemah dan Tafsir al-Qur'an dalam huruf Arab
\& Latin juz 6-10. Bandung: Angkasa, 2004.

Suyanto, M. Muhammad Business Strategy \& Ethics (Etika dan Strategi Bisnis Nabi Muhammad SAW). Yogyakarta: ANDI, 2008. 